\title{
How to Boost Faculty Research Performance in HEI's to Improve Intellectual Property by Integrating it with Faculty Compensation - A "Theory of Accountability" based Framework
}

\author{
P. S. Aithal \\ Srinivas Institute of Management Studies, Srinivas University, Mangalore - 575 001, INDIA \\ E-mail: psaithal@gmail.com
}

Type of the Paper: Research Paper.

Type of Review: Peer Reviewed.

Indexed in: OpenAIRE.

DOI: https://doi.org/10.5281/zenodo.1689055.

Google Scholar Citation: IJMTS

\section{How to Cite this Paper:}

Aithal, P. S. (2018). How to Boost Faculty Research Performance in HEI's to Improve Intellectual Property by Integrating it with Faculty Compensation-A "Theory of Accountability” based Framework. International Journal of Management, Technology, and Social Sciences (IJMTS), 3(2), 129-150. DOI: https://doi.org/10.5281/zenodo.1689055.

International Journal of Management, Technology, and Social Sciences (IJMTS) A Refereed International Journal of Srinivas University, India.

(C) With Authors.

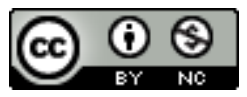

This work is licensed under a Creative Commons Attribution-Non Commercial 4.0 International License subject to proper citation to the publication source of the work.

Disclaimer: The scholarly papers as reviewed and published by the Srinivas Publications (S.P.), India are the views and opinions of their respective authors and are not the views or opinions of the SP. The SP disclaims of any harm or loss caused due to the published content to any party. 


\title{
How to Boost Faculty Research Performance in HEI's to Improve Intellectual Property by Integrating it with Faculty Compensation - A “Theory of Accountability" based Framework
}

\author{
P. S. Aithal \\ Srinivas Institute of Management Studies, Srinivas University, Mangalore - 575 001, INDIA \\ E-mail: psaithal@gmail.com
}

\begin{abstract}
The objective of campus based higher education is now shifting from mass education to customized education and in such model involving students in research by faculty members is an essential part. Such research focused higher education model not only benefits the students but also provides an opportunity for the institution to create intellectual property in its name. To encourage faculty members to be involved in research and publications, higher education institutions (HEIs) are trying to find various strategies. Faculty compensation is one of the important strategies in higher education institutions as faculty members are the brain of the system and creators of an intellectual asset to the institution. Making faculty compensation dynamic is a very attractive and effective way in order to involve faculty members in research and publications. In this paper, we have studied the changing objectives of autonomous HEIs like private universities towards developing Intellectual property by shifting their focus towards research and publications using their financial autonomy. As a part of such initiatives, an improved model of faculty compensation is proposed based on Annual Performance Based Component (APBC) and discussed how it adds value to the HEIs by inspiring the faculty member's involvement and accountability to create a tangible asset of intangible intellectual property. The paper also discusses the cases of pessimistic expectations, most-likely expectations, and optimistic expectations of faculty performance and its financial implications on the institution by simulating these estimates.
\end{abstract}

Keywords: HEI, Faculty performance, Dynamic Faculty compensation, Theory of Accountability, Factors affecting faculty performance.

\section{INTRODUCTION :}

Higher Education Institutions (HEI) are the part of the education industry which is a part of the tertiary sector service industry in the society. With the objective of providing quality service to the students, industries, and society, HEIs are claiming autonomy to improve the quality through independent decisions at the institution level. In this regard, private universities in the world over have higher autonomy including making their financial decisions compared to public universities and other affiliated institutions (private or public) [1-3]. The quality aspect in HEI service is defined, delivered, and received by various stakeholders of the HEI system [4-10]. In HEI system, the primary (internal) stakeholders are students, teachers, and management. Other (external) stakeholders are industry, alumni, government, and other accreditation institutions. The responsibilities of HEIs towards students, industries, and society are different and accordingly, they decide their objectives and set their targets to realize the objectives [4, 11-13]. 
Table 1 : Objectives of autonomous HEI towards stakeholders

\begin{tabular}{|l|l|l|}
\hline S. No. & Stakeholders & Objectives \\
\hline 1 & Students & $\begin{array}{l}\text { Imparting knowledge, skills, experience, ethics, and hence } \\
\text { confidence to make them innovative independent thinkers. }\end{array}$ \\
\hline 2 & Industries & $\begin{array}{l}\text { Providing innovative graduates who can contribute effectively and } \\
\text { efficiently for organizational productivity/ performance by } \\
\text { transforming them innovative independent thinkers\& team players. }\end{array}$ \\
\hline 3 & Society & $\begin{array}{l}\text { New knowledge, New interpretation of existing knowledge, by } \\
\text { means creating,managing, and utilizing researching abilities of the } \\
\text { intellectuals to createintellectual property. }\end{array}$ \\
\hline
\end{tabular}

Quality of higher education is considered as a service due to the reason that it is produced as a result of human labour and is intangible quantity developed as per the needs of the market. The quality in higher education depends on the organizational culture and tradition which further depends on four determinant factors including the quality of human resources (faculty \& administrators), the way of managing the system, useful education programmes\& methods, and the infrastructure which include buildings, facilities, and equipment [14]. These performance or level quality determinant factors should meet the requirements of potential beneficiaries (students, industries, and society) [11]. The importance of these four quality determinant factors are further discussed below : (1) Quality of Human Resources : Quality of human resources include the quality of teaching, training, and the capability of creating new knowledge through and innovation by the faculty and students of the institution. Student involvement in research provides a new model of education called customised education which an effective strategy against the competition of distance education \& MOOC based degree programmes.

(2) Quality of Administrative \& Managing system :The decisions taken by the administrative executives on creating, developing, maintain and further investment strategies and their vision, mission, and objectives both for the long term and short term in the higher education system are important to sustain the quality as well as to create a brand to the organization.

(3) Quality of useful education programmes \&methods : Right courses and right pedagogy are essential to attract and educate students in the higher education system. Offering industry oriented and industry integrated courses and designing \& implementing effective education and evaluation methodologies are supports quality in higher education.

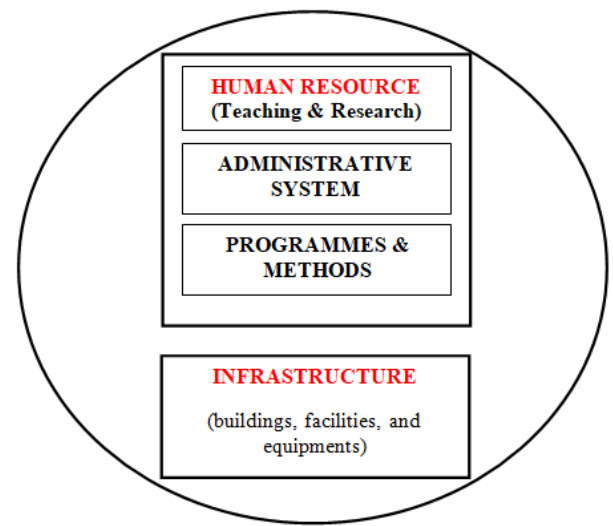

Fig. 1 :Internal Quality framework of Higher Education System

(4) Quality of Infrastructure : Infrastructure is a very important determinant factor in attracting students to the HEI. Infrastructure includes land, buildings, and facilities like modern classrooms, modern library, sports \& games, residential facilities both for students and faculties, state-ofart laboratories \& workshops, auditorium, etc. for an ultra modern campus. But usually, high quality infrastructure increases the cost of education and hence student fee. Infrastructure gives an added advantage to the higher education system when other three quality determinant factors are appropriate. Based on the above analysis, we can reframe the internal quality framework of higher education in a 
broad way as shown in figure 1 .

Based on quality framework approach of HEI system, it can be argued that the Intellectual Property (IP1) of HEI which decides the quality of human resource, administrative setup, and programmes \&methods, and Infrastructural Property (IP2) are two major determinant issues which describe the quality and performance of HEI's. Human resource/capital is the most critical asset in HEIs and using human resource/capital effectively to contribute and build the intellectual property of the organization is most important challenge and tactic for HEIs administrators [4].

\section{OBJECTIVES :}

The objectives of this paper is to find out the new trends in autonomous higher education institutions which include :

- The changing focus required to differentiate themselves in competitive global higher education models.

- To find out the shifting focus of world top universities to improve the internal quality framework.

- The importance of building intellectual property and infrastructural property in creating value and competitiveness globally.

- The strategy to improve the intellectual property of HEIs by focusing on student
\& faculty research at UG, PG, and research curriculum, and

- Proposing a new model on how to boost the faculty performance in contributing research and publication by integrating faculty annual performance with faculty compensation.

\section{IMPORTANCE OF IP(1) \& IP(2) IN} HIGHER EDUCATION INSTITUTIONS :

Identifying and appointing suitable faculty members who have inherent interest and capabilities to participate in research and contribute for new knowledge creation both individually and through team work and skill of publishing them in journals and books or patenting them in institutional name to generate intellectual property should be given priority in HEIs. Creating new knowledge and converting it into IP-1 is important to higher education institutions for their accelerated growth and competitive advantage. Intellectual property of a HEI comprising of published journal papers, Conference papers, edited books, published books, published edited chapters, filed patents, copyrights, trademarks, designed rights, and Thesis books of masters, Ph.D., and postdoctoral degrees are very important accumulated intellectual property which may give earning opportunity, branding opportunity, public value creation, and international recognitions [15-24].

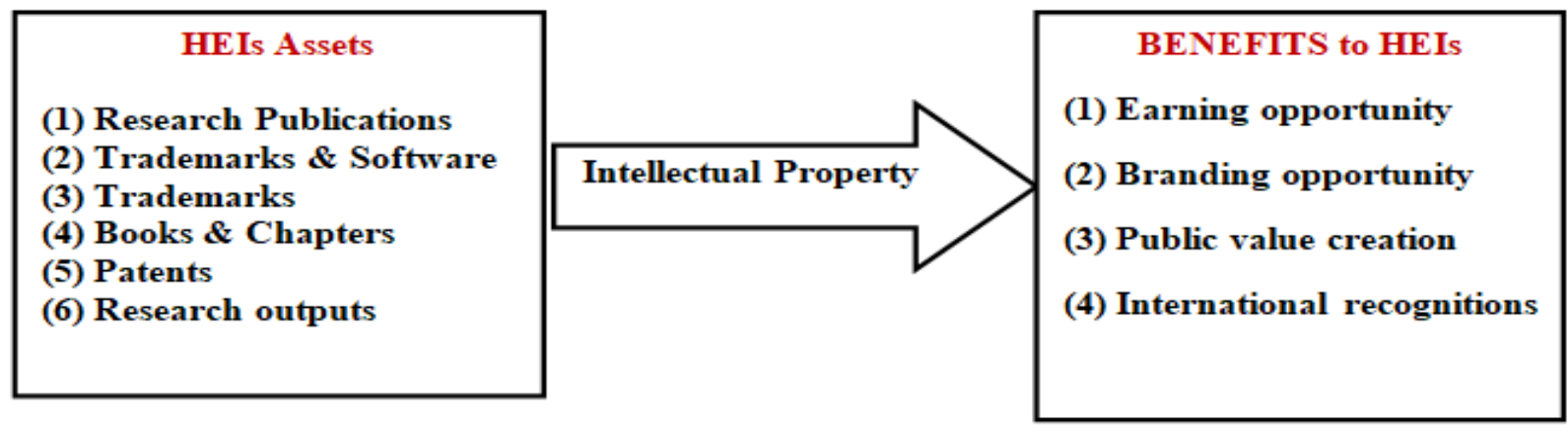

Fig. 2 : Block diagram representing HEIs assets as Intellectual Property and its benefits.

It is observed that earlier, private universities have given less importance to research than offering new attractive courses along with attractive infrastructure. As a result, a larger share of research contribution is registered from public universities. As time progress, private universities realized that only infrastructure and new courses cannot differentiate them and give competitive advantage in higher education service offerings due to the fact that 
infrastructure and new course offerings can be provided at any time by other rivalry institutions and any new entrants to this business. Such universities which give importance to long time differentiation through research can only compete and sustain in a longer period. By realizing this truth of "Focusing on research \& publication for enhanced sustainability" higher education institutions are changing their strategy and focusing on research and publications. In the process of such shifted focus from infrastructure to research and publication, HEIs are now changing their objectives, promoting research based curriculum and encouraging their faculty members and students to involve in research and publications. The advantages of research focus by autonomous HEIs by setting up a supportive environment is of many folds :

(1) Focus on research in teaching \& training differentiates the campus based higher education model from a massive open online course (MOOC) model which is an information communication technology version of the distance education model.

(2) Faculty members and students become active members of the system contributing to the new knowledge.

(3) Higher education system becomes the dynamic contributing intellectual property of the HEIs so that as time progress, the intellectual asset of the institution/university grows in terms of both quantity and quality.

(4) Based on the research focus of the institution, the faculty members get enhanced support and motivation in order to convert their ideas and new concepts into new knowledge or new interpretation leading to a systematic documentation of such new invention or innovation in published format.

(5) Focus on scientific research in classrooms by involving students helps them to develop critical reasoning skills which are helpful to develop confidence for innovative thinking and crystallizing ideas in future days throughout their life.

(6) Publishing the research findings and analysis in the national or international forum helps both faculty members and students to improve their systematic analysing ability, along with oral and written communication skills. This will automatically improve the quality of teaching and learning processes of both faculty members and students in the classrooms respectively.

Based on above facts, many autonomous universities especially private universities under higher education institutions have changed their objectives and converted themselves as research intensive universities [25]. They have identified and developed suitable strategies to increase their research productivity by including both faculty members and students in developing and implementing research based curriculum [2628].

Research intensive university primarily meets three criterions : (1) Focus on new knowledge creation, (2) Inherent spirit on critical inquiry, (3) Selecting faculty and students who have research interest. Many universities developed countries meet these criterions and branded as successful research universities. For example, the list of top 10 universities of 2018 in the USA as per www.Timeshighereducation.com and www.topuniversities.com are listed in Table 2 and it can be seen that all of them are research focussed private universities.

Table 2 : Top ten ranked universities in the USA

\begin{tabular}{|l|l|l|l|l|}
\hline S. No. & Top Ranked Universities & Rank & Type & Focus \\
\hline 1 & Stanford University & First & Private & Research focus \\
\hline 2 & $\begin{array}{l}\text { Massachusetts Institute of } \\
\text { Technology (MIT) }\end{array}$ & Second & Private & Research focus \\
\hline 3 & $\begin{array}{l}\text { California Institute of } \\
\text { Technology (CalTech) }\end{array}$ & Third & Private & Research focus \\
\hline
\end{tabular}


International Journal of Management, Technology, and Social

\begin{tabular}{|c|c|c|c|c|}
\hline 4 & Harvard University & Fourth & Private & Research focus \\
\hline 5 & Princeton University & Fifth & Private & Research focus \\
\hline 6 & University of Chicago & Sixth & Private & Research focus \\
\hline 7 & Cornell University & Seventh & Private & Research focus \\
\hline 8 & Yale University & Eighth & Private & Research focus \\
\hline 9 & $\begin{array}{l}\text { John Hopkins University / } \\
\text { University of Pennsylvania }\end{array}$ & Ninth & Private & Research focus \\
\hline 10 & Columbia University, New York & Tenth & Private & Research focus \\
\hline
\end{tabular}

\section{FACULTY COMPENSATION IN HIGHER EDUCATION INSTITUTIONS :}

Various models of compensation for employees are used in the history in both production and service industries. This includes Pay for performance (P4P) model, Performance based bonus, Stock based compensation, Earning based compensation. Equality based compensation etc.

(1) Pay for performance (P4P) model :Pay for performance refers to a pay strategy where evaluations of individual and/or organizational performance have a significant influence on the amount of pay increase or bonus given to each employee.

(2) Performance based bonus: It is a type of additional compensation to be paid to an employee or group of employees as a reward for completing a particular task.

(3) Stock based compensation : This type of compensation involves the distribution of company stock to reward the performance of employees.

(4) Earning based compensation : This type of compensation in its simple terms involves the earnings of shares of the company during a given year and accordingly the compensation of executives is offered.

(5) Equality based compensation :In this type of compensation, the earnings of the employees are the same in a given grade/designation irrespective of their performance. Many organizations in the public sector and few of private sector organizations follow this model.

(6) Equity based compensation :It is a non-cash payment that represents ownership in the company. It may take different forms like options, restricted stock, and performance shares.

Productivity based compensation and Performance based compensation are two general types of meaningful compensation for production industries and service industries respectively. In the case of Higher Education Institutions industry, usually, the faculty compensation is defined by their responsibilities in a specified designation which consists of teaching, research, administrative and/or clinical. The total compensation is sum of various components which may include (1) fixed component based on their designation and years of service in that designation, (2) fixed allowances based on fixed component, and (3) variable component based on annual academic performance indicator score and is called as Annual performance based component (APBC). This variable component is a very important part in every pay structure and essential to differentiate the employee contribution in organizational development.

In this paper, we have developed and discussed an improved model of faculty compensation based on Annual Performance Based Component (APBC) and discussed how it adds value to the HEIs to create a tangible asset of intangible intellectual property. Annual Performance Based Component is nothing but 
the contribution of a faculty to research and publication leading to the contribution to intellectual property (IP-1) asset of the HEI.

\section{THEORY OF ACCOUNTABILITY IN HEI :}

Organization and hence faculty members accountability towards their students, industry, and society are now getting importance and becoming increasingly significant in Higher Education system over the past decades due to the reasons of increased competitions without expected quality, rising of HEI institutions costs, disappointing un-employability rate of graduates, employer concerns on inadequate knowledge and skills expected in the workplace, and comments on the learning and value that higher education system provides to the students.

Faculty accountability in higher education system became important in many countries during the last few decades of $20^{\text {th }}$ century and many faculty performance indicators were developed to improve productivity and for institutional effectiveness. By the end of $20^{\text {th }}$ century, many accountability reporting systems were mandated in many countries through their higher education accreditation boards. During the beginning of $21^{\text {st }}$ century, much importance and encouragement are given to the institutional autonomy both in public and private sectors to re-define quality through organizational and faculty autonomy. This move encouraged many private universities to accelerate their quality improvement strategy due to the reason that they have financial as well as quick decision making freedom on various determinant factors of quality improvement in higher education. This autonomy resulted in speeding up the process of faculty accountability and encouragement to improve the quality, as well as a contribution to the society through their enhanced focus on creating more and more intellectual property in a time-phased manner. The quest for creating intellectual property by higher educational \& research institutions is now given importance to faculty accountability in intellectual property creation along with teaching and training. Every faculty in higher education institution has the responsibility of involving in teaching \& training as well as in research \& publications. Research is an integrated component in the higher education system at the undergraduate level and postgraduate level by involving students in such activities. Autonomous HEIs have potential opportunity to introduce project based, case analysis, or patent analysis as qualitative research for undergraduate courses in association with faculty members as guides. Similarly, postgraduate students can be involved in projects related to conceptual designs, explorative studies, data analysis, decision analysis, simulation, and empirical studies under the guidance of faculty members. These innovations in undergraduate and postgraduate curriculum open doors for student-faculty collaborative research and publications. Each such scholarly publication in the form of journal paper, conference paper, patent, chapters in edited books, or complete edited book published in the name of the institution is considered as the intellectual property of HEI and such accumulated intellectual property is the intangible but convertible asset of that institution. Creation, accumulation, and branding of such asset is the opportunity for faculty members of autonomous HEIs and challenge for administrators. Based on the idea of converting this intellectual property into an organizational asset for brand building and institutional performance indicator in the international scenario, HEIs have tremendous interest in encashing this opportunity. Creating and maintaining such intellectual property is a challenge for HEIs and if not planned and managed properly, they will lose a great chance of creating this priceless intangible asset for the organization using existing faculty members and students without any additional substantial investment. We strongly urge that the autonomous HEIs especially private universities have to really and seriously think on these lines and focus their attention in creating intellectual property (IP-1) as a precious asset and to accumulate it every year. Even though research and publication is an integral part of the duty of every faculty member in higher education, making them responsible in contributing to it is 
a serious challenge to the administrators. This can be addressed using recently developed organizational performance theory called Theory of Accountability (Theory A). Theory A identifies the various factors which affect the organizational human resources performance. The emphasis is on inspiration and accountability of employees. This theory is developed during 2016 by P. S. Aithal and P. M. Suresh Kumar [29]. The postulates of Theory A override the existing propositions of various theories of organizational human behaviour and motivation by adding a new and extended set of propositions to improve the productivity based on human performance. By controlling employees mindset and quest for creativity in a systematic way, propels the employees to contribute to the objectives of the organization. Using Theory A, any organization in every industry sector can develop their strategy to boost their output by enhancing operational efficiency. Implementation of the propositions of theory A enables organizations to accelerate the contribution of their employees by connecting the targets with responsibility and commitment which is further stimulated by comparing with role models and setting accountability. The essential ingredients of Theory A [29-40] are (1) Planning the task based on objectives, (2) Target setting for every employee, (3) Motivation for achievement, (4) Developing Work Strategies, (5) Commitment through Responsibility, (6) Role model for comparison, (7) Continuous follow-up through Monitoring \& Guiding, and (8) Accountability as positive or negative encouragement.

The postulates of theory A connect the following factors of organizational performance [29] :

(1) Planning :As per Theory A, the vision, mission, and objectives of an organization should be clear on the organizational contribution towards development. Planning is the first determinant component of the theory A and finds a prominent role in transforming an organization by an optimized contribution from its employees. Theory A promotes employee planning in order to improve their contribution by understanding the organizational objectives. By jointly setting the objectives of the organization, an organization can encourage its employees to think and contribute innovatively. Theory A also suggests that the organization can develop its planning strategy as the blue ocean to become a monopoly in its business. The planning component of theory A also supports the involvement of employees in analysing the institutional strengths, weaknesses, opportunities, and challenges, either individually or jointly in order to transform the organization into a highly productive organization [30].

(2) Target setting :Target setting is the second determinant component of Theory $\mathrm{A}$ and is include setting the time bound target of individual and group of employees of the organization. Target can be set for the entire number of employees individually as activity target or jointly as output target. Time bound targets can be fixed for quarterly, half yearly, or annually based on institutional policy and should be communicated in time to every employee in the organization. Such a simulative environment creates challenges for the employees and makes them to redefine their individual and group goal. The strategy of target setting for individuals and groups in an organization according to theory A makes everybody to prepare and devote their effort towards better performance [31].

(3) Motivation :Motivation in Theory A is the third component and is helpful to the employees to discover their own potential through selfexploration. As per theory A, once the target for the optimum performance by the employees is set, the authorities of the organization should develop and implement policies to help the employees to meet the targets. Theory A identifies various motivational factors which support to identify weaknesses of employees, encouragement to perform at par with others, appreciation of individual contribution and performance, encouragement for collaborative works, developing task-based strategies for better performers etc [32].

(4) Work Strategies :Work strategy being the fourth component of Theory A is important for success. Work strategy promotes a time-frame plan for individuals and groups to fulfil their target. Thus, Theory A proposes teamwork through collaborative efforts with other people 
simultaneously as a multitasking model. Redefining the target based on its successive fulfilment is another enabling part of the work strategies [33-34].

(5) Responsibility :Being major component of Theory A, responsibility at workplace contributes to both individual and organizational success. When the employees show their responsibility towards contributing towards the organizational objective, the productivity of the organization will enhance. It is argued that based on personality type, only a few people can take responsibility by themselves for organizational contribution. External stimulus is required for others to point out their responsibilities. Other components of Theory A like target setting, motivation, encouragement, continuous followup, or showcasing a role model in internal or external to the organization is also to stimulate the responsibility among the employees [34].

(6) Role model :Employees in every organization should realize that a given challenge through target setting is possible to achieve. Only achievable objectives should be set while target setting stage. By showcasing the role models either internal or external to the organization in a similar field, any organization can build confidence among the employees and prove that the set targets can be achievable. A role model can be any employee in the organization who outperform and contribute highest to the organization. Irrespective of age, gender, position and any kind of administrative responsibilities, role models can inspire all members of the organization and demonstrate that higher productivity is possible despite constraints. As per Theory A, an organization can showcase the performance of role models to improve targets and hence employee performance [35].

(7) Monitoring \&Guiding :The next component of Theory A is continuous monitoring of the employees performance and accelerating the productivity of the organization. Such stage will automatically create responsibility and avoid redundancy. Monitoring process in theory A includes both self-monitoring and monitoring by superiors. Continuous monitoring and guiding process provides confidence among the employees and will keep the team together [36].

(8) Accountability :According to Theory A, accountability should be fixed to every member of the organization including the heads of the departments so that satisfaction and justice among the employees can be maintained in the organization. The accountability is hallmark of success or failure of an individual or teams. Accountability is the final component of this organizational performance model for individuals and is either positive or negative depending on organizational policy for achievers or losers respectively [37].

\subsection{Theory of Accountability for HEI :}

Higher education sector is a service industry and the service provided to the students is usually intangible. The outcome of the teaching and learning process can be converted into tangible by means of conducting examination, evaluation, and certificate with the marks card. Similarly, the intangible research and intellectual property component can be converted into tangible by means of publications and patents. In higher education system, faculty members are responsible in developing intellectual property for the institution using UG, PG, and research students. As per the new model, faculty members can be trained and motivated towards contributing to the intellectual property using all the eight stages of theory of accountability. As per this model, the responsibility component of Theory A can be stimulated by integrating faculty performance with their compensation. This provides monetary benefits to the faculty and hence contributes to solve his/her personal problems also. Thus, many faculty members set their action plan and invest their time for increasing their contribution for enhancing intellectual property of the organization. As per the propositions of this integrated model, the faculty performance is integrated with salary compensation. The total pay is the sum of base scale (BS), Annual increment (AI), Variable dearness allowance (DA), and Annual performance based component (APBC) which is a variable component and its value depends on the annual Academic Performance Indicator 
(API) score.

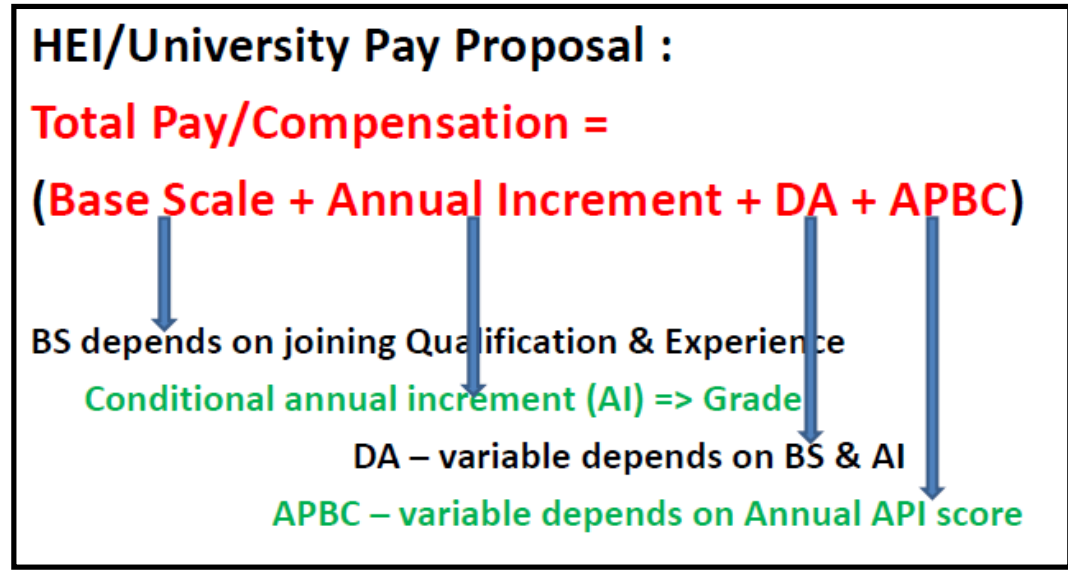

Fig. 3 : Model on integrating faculty performance with faculty compensation

$S_{n}(t)=\left[B_{n}(t)\right]+\left[D\left(B_{n}(t)\right]+[P(t)]\right.$

Where $\mathbf{B}_{\mathbf{n}}(\mathbf{t})=\left[\mathbf{B}_{(\mathbf{n}-1)}(\mathbf{t})+\mathbf{I}\right]$

$$
\mathbf{P}(\mathbf{t})=[\mathbf{A \alpha}]
$$

Where $\mathrm{S}(\mathrm{t})$ = total salary in a given grade in a given year $\mathrm{t}$.

$\mathrm{B}(\mathrm{t})=$ Base scale in a given year $\mathrm{t}$

$\mathrm{D}=$ Annual Dearness Allowance in percentage (\%)

$\mathrm{I}=$ Annual increment (conditional) $=\mathrm{x} / 0$ depending on required publications claimed by one faculty only

$\mathrm{n}=$ Total year of experience in a given cadre/grade after joining the university

$\mathrm{P}(\mathrm{t})=$ Performance Component

$\alpha=$ Annual Performance score calculated using API policy

$\mathrm{A}=$ The monitory benefit in rupees for the faculty per API score

Table 3 : Perspective of Theory A for Faculty members of HEIs

\begin{tabular}{|l|l|l|}
\hline S. No. & Stages of Theory A & Faculty Members Point of view \\
\hline 1 & Planning & To be a research focused faculty \\
\hline 2 & Target Setting & Time based research and publication \\
\hline 3 & Developing Motivation & $\begin{array}{l}\text { Creating habit of research information collection } \\
\text { and innovative thinking }\end{array}$ \\
\hline 4 & Devising Work strategies & $\begin{array}{l}\text { Collaborative research teams and identifying new } \\
\text { research methods \& opportunities }\end{array}$ \\
\hline 5 & Creating Responsibility & Struggle to meet the time bound target \\
\hline 6 & Identifying Role Model & $\begin{array}{l}\text { Role model Researchers enhances confidence of “it } \\
\text { is possible” and hence increases commitment }\end{array}$ \\
\hline 7 & Monitoring and Guiding & Performance Evaluation and follow-up \\
\hline 8 & Imposing Accountability & Increases performance and effectiveness \\
\hline
\end{tabular}

\section{FACTORS AFFECTING FACULTY INVOLVEMENT IN RESEARCH \&CONTRIBUTING TO IP (1) :}

Every qualified faculty member teaching undergraduate and postgraduate students are supposed to involve in research and publications. The slogan - "Publish or Perish"is perfectly relevant in these days due to internal competition and global competition among many universities throughout the world. Universities and other autonomous higher 
educational institutions are looking for opportunities to differentiate themselves. In this regard, many private universities in India believed that this is the right time to motivate and inspire their faculty members to involve in research and publications by setting the appropriate targets. There are two types of factors affecting faculty members contribute to research and publications :

\section{A. Favourable Motivational Factors:}

(1) Strong desire to achieve and contribute to new knowledge.

(2) Personal desire to grow in the career by contributing and publishing.

(3) Institutional offers \& Individual benefits.

(4) Opportunity to become a part of a research group in my interested field.

(5) Obtained research fellowship through NET/SLET exam.

(6) Availability time for research and satisfaction through contribution.

(7) Research \& publication is my passion.

(8) Inspired by many researchers who have contributed substantially to society.

(9) Institutional encouragement and support for monitory \& other benefits for taking part.

(10) Individual accountability based on Institutional objectives of research focus.

(11) Institutional requirement to obtain research degrees.

(12) Requirement of publications and research degrees for faculty members for institutional NAAC and NIRF rankings.

(13) Mandatory Ph.D. degree requirement for college \& University Teachers as per MHRD regulations.

(14) Institutional pressure and targets.

(15) Individual accountability towards the institutional intellectual property.

(16) Responsibility of individual faculty towards their institutional international branding.

B. Unfavourable De-motivational Factors:

(1) Financial constraints.

(2) Time constraints.

(3) Struggle to pass NET/SLET to get eligibility.

(4) Fear in taking challenge due to inferiority and hence procrastination.

(5) Identifying the research topic \& suitable guide.
(6) Personal \& Other commitments.

(7) Age and experience factors.

(8) Commenting \& Condemning the research due to the personal psychology of Negative thinking.

(9) No compulsion from the institution to maintain accountability.

(10) Many of my juniors completed Ph.D., I could not \& cannot. So, I hate it.

(11) No opportunity to register as a part timer/full timer.

(12) No research facilities in my subjects around for experimental research.

(13) Commitment for four to five years is difficult.

(14) No motivation \& support from family members and their working institution.

(15) No consideration in promotion/increment and monitory benefits for research \& Publication.

(16) What is the benefit individually for faculties?

(17) Satisfied with the present grade. No plan of career development \& progress.

(18) Gender related problems.

Based on above we suggest few propositions to the HEIs including universities to encourage research and publications to their faculty members. These propositions are derived from the elements of theory A and are certainly becomes motivational and accountability factors to boost annual research output and hence intellectual property of the organizations :

Proposition1 :Higher educational institutions/universities should redefine their objectives and convert them as research institutions or research universities by shifting their focus to develop intellectual property.

Proposition 2 :Higher educational institutions should use their autonomy to include research components which help for new knowledge creation or new interpretation of existing knowledge in their UG and PG curriculum to include students in research process.

Proposition 3 : Faculty members should be trained and inspired to set their goal as research contributors and research guides to their students along with regular teaching and training.

Proposition 4 : Higher education institutions 
should inspire their faculty members by appointing some super researchers as role models who can inspire all other faculty members to re-define their target and get confidence in achieving it.

Proposition 5 :Higher education institutions should initiate various activities which create research atmosphere and facilities in the organization including organizing conferences, and training on how to publish research output systematically.

Proposition 6 : Higher education institutions should initiate a monitoring system for faculty Performance Evaluation and follow-up by continuous monitoring and counselling individual faculties.

Proposition 7 :To ensure faculty accountability, Higher education institutions should integrate faculty performance with compensation and offer monitory benefit by converting their intellectual property contribution to monitory benefits.

Proposition 8 : Faculty accountability can be encouraged further positively by offering faculty Ranking in each college/ department of the institution and offering appreciation certificates/rewards in annual celebrations/annual reports.

\section{A PROPOSAL OF FACULTY COMPENSATION FRAMEWORK BASED ON THEORY A :}

In order to implement the propositions 7 and 8, on ensuring faculty accountability, higher education institutions can implement dynamic pay scale as faculty compensation with inclusive faculty performance component called Annual performance based component (APBC) along with conditional annual increment as shown in table 4. The salary proposal based on Theory A consists of four components as basic pay at a given grade, annual conditional increment, dearness allowance (depends on conditional increment), and annual performance based component (APBC). The faculty grades or designation equivalence in India and USA are compared and given in table 5. APBC is calculated annually based on faculty contribution to intellectual property as per the guidelines given in annual academic performance indicator chart as shown in table 6 .

Table 4 :Autonomous Institution/University Pay Structure Proposal

\begin{tabular}{|c|c|c|c|c|}
\hline $\begin{array}{l}\text { S. } \\
\text { No }\end{array}$ & Grade & Qualification & $\begin{array}{l}\text { Experience \& } \\
\text { Journal Papers }\end{array}$ & $\begin{array}{l}\text { Min Basic Scale \& } \\
\text { Annual Increment }\end{array}$ \\
\hline 1 & $\begin{array}{l}\text { Research Scholars } \\
\text { (8 periods/week } \\
\text { teaching } \\
\text { assistantship) }\end{array}$ & $\begin{array}{l}\text { Full Time Master Degree in } \\
\text { Respective subject with } 60 \\
\% \text { marks \& NET/SLET }\end{array}$ & - & $\begin{array}{l}8,000 / 9,000 / 10,000 \\
\text { in the first/second / } \\
\text { third year }\end{array}$ \\
\hline 2 & $\begin{array}{l}\text { Assistant Lecturer } \\
(18 \text { periods/week } \\
\text { teaching) Rs. } \\
\text { 800/year }\end{array}$ & $\begin{array}{l}\text { Full Time Master Degree in } \\
\text { Respective subject with } \\
60 \%\end{array}$ & - & $\begin{array}{l}\text { 18,000 } \\
\text { with Rs. 800/year }\end{array}$ \\
\hline 3a & $\begin{array}{l}\text { Lecturer } \\
\text { Rs. 1,000/year }\end{array}$ & $\begin{array}{l}\text { Full Time Master Degree in } \\
\text { Respective subject with } \\
60 \% \text { \& NET/SLET/M.Phil. }\end{array}$ & 2 Years & $\begin{array}{l}22,000 \\
\text { with Rs. 1,000/year }\end{array}$ \\
\hline $3 b$ & $\begin{array}{l}\text { Lecturer (Tech) } \\
\text { Rs. } 1,000 / \text { year }\end{array}$ & M.Tech. with Min. 60\% & - & $\begin{array}{l}24,000 \\
\text { with Rs. 1,000/year }\end{array}$ \\
\hline $4 a$ & $\begin{array}{l}\text { Sr. Lecturer } \\
\text { Rs. } 1,200 / \text { year }\end{array}$ & $\begin{array}{l}\text { Full Time Master Degree in } \\
\text { Respective subject with } \\
60 \% \text { \& NET/SLET/M.Phil. }\end{array}$ & $\begin{array}{l}5 \text { Years } \\
\text { (Registered } \\
\text { Ph.D. \& } \\
\text { paper/year) }\end{array}$ & $\begin{array}{l}27,000 \\
\text { with Rs. 1,200/year }\end{array}$ \\
\hline $4 \mathrm{~b}$ & $\begin{array}{l}\text { Sr. Lecturer (Tech) } \\
\text { Rs. 1,200/year }\end{array}$ & $\begin{array}{l}\text { M.Tech. with Min. 60\% in } \\
\text { respective subject }\end{array}$ & $\begin{array}{l}5 \text { years } \\
\text { (Registered }\end{array}$ & $\begin{array}{l}29,000 \\
\text { with Rs. 1,200/year }\end{array}$ \\
\hline
\end{tabular}


International Journal of Management, Technology, and Social

\begin{tabular}{|c|c|c|c|c|}
\hline & & & $\begin{array}{l}\text { Ph.D. \& } \\
\text { paper/year) }\end{array}$ & \\
\hline 5 & $\begin{array}{l}\text { Assistant Professor } \\
\text { (Institutional-Level 1) } \\
\text { Rs. 1,500 }\end{array}$ & $\begin{array}{l}\text { Full Time Master's Degree } \\
\text { in Respective subject with } \\
60 \% \text { \& NET/SLET/M.Phil. }\end{array}$ & $\begin{array}{l}10 \text { Years } \\
\text { (2 papers/ year) }\end{array}$ & $\begin{array}{l}35,000 \\
\text { with Rs. 1,500/year }\end{array}$ \\
\hline 6 & $\begin{array}{l}\text { Assistant Professor } \\
\text { (Institutional-Level 2) } \\
\text { Rs. 1,600 }\end{array}$ & $\begin{array}{l}\text { Full Time Master's Degree } \\
\text { in Respective subject with } \\
60 \% \text { \& NET/SLET/M.Phil. }\end{array}$ & $\begin{array}{l}15 \text { Years } \\
\text { (2 papers/ year) }\end{array}$ & $\begin{array}{l}43,000 \\
\text { with Rs. 1,600/year }\end{array}$ \\
\hline 7 & $\begin{array}{l}\text { Associate Professor } \\
\text { (Institutional) } \\
\text { Rs. } 1,800\end{array}$ & $\begin{array}{l}\text { Full Time Master Degree in } \\
\text { Respective subject with } \\
60 \% \text { \& NET/SLET/M.Phil. }\end{array}$ & $\begin{array}{l}20 \text { Years } \\
\text { (2 papers/ year) }\end{array}$ & $\begin{array}{l}51,000 \\
\text { with Rs. 1,800/year }\end{array}$ \\
\hline 8 & $\begin{array}{l}\text { Professor } \\
\text { (Institutional) } \\
\text { Rs. 2,000) } \\
\end{array}$ & $\begin{array}{l}\text { Full Time Master Degree in } \\
\text { Respective subject with } \\
60 \% \text { \& NET/SLET/M.Phil. }\end{array}$ & $\begin{array}{l}25 \text { Years } \\
\text { (2 papers/ year) }\end{array}$ & $\begin{array}{l}60,000 \\
\text { with Rs. 2,000/year }\end{array}$ \\
\hline 9 & $\begin{array}{l}\text { Assistant Professor } \\
\text { (Level 1 UGC) } \\
\text { Rs. 2,000 }\end{array}$ & $\begin{array}{l}\text { Full Time Master Degree in } \\
\text { Respective subject with } \\
60 \% \text { \& Ph.D. }\end{array}$ & $\begin{array}{l}0 \text { Years } \\
\text { (5 Journal Paper \& } \\
2 \text { papers /year) }\end{array}$ & $\begin{array}{l}50,000 \\
\text { with Rs. 2,000/year }\end{array}$ \\
\hline 10 & $\begin{array}{l}\text { Assistant Professor } \\
\text { (Level } 2 \text { UGC) } \\
\text { Rs. 2,000 }\end{array}$ & $\begin{array}{l}\text { Full Time Master's Degree } \\
\text { in Respective subject with } \\
60 \% \text {, Ph.D., } 3 \text { years } \\
\text { experience after Ph.D. }\end{array}$ & $\begin{array}{l}3 \text { years } \\
\text { (10 Journal Paper } \\
\& 2 \text { papers /year) }\end{array}$ & $\begin{array}{l}60,000 \\
\text { with Rs. 2,000/year }\end{array}$ \\
\hline 11 & $\begin{array}{l}\text { Assistant Professor } \\
\text { (Level } 3 \text { UGC) } \\
\text { Rs. 2,000 }\end{array}$ & $\begin{array}{l}\text { Full Time Master's Degree } \\
\text { in Respective subject with } \\
60 \% \text { Ph.D., } 5 \text { years } \\
\text { experience after Ph.D. }\end{array}$ & $\begin{array}{l}5 \text { years } \\
\text { (15 Journal Paper } \\
\text { \& } 2 \text { papers /year) }\end{array}$ & $\begin{array}{l}65,000 \\
\text { with Rs. 2,000/year }\end{array}$ \\
\hline 12 & $\begin{array}{l}\text { Associate Professor } \\
\text { (Level 1 UGC) } \\
\text { Rs. 2,300 }\end{array}$ & $\begin{array}{l}\text { Full Time Master Degree in } \\
\text { Respective subject with } \\
60 \% \text { Ph.D., } 8 \text { years } \\
\text { experience after Ph.D. }\end{array}$ & $\begin{array}{l}8 \text { years } \\
\text { (20 Journal Paper } \\
\& 3 \text { papers /year) }\end{array}$ & $\begin{array}{l}72,000 \\
\text { with Rs. 2,300/year }\end{array}$ \\
\hline 13 & $\begin{array}{l}\text { Professor (Level 1) } \\
\text { Rs. 2,600 }\end{array}$ & $\begin{array}{l}\text { Full Time Master Degree in } \\
\text { Respective subject with } \\
60 \% \text {, Ph.D., } 10 \text { years } \\
\text { experience after Ph.D. }\end{array}$ & $\begin{array}{l}10 \text { years } \\
\text { (25 Journal Paper } \\
\& 4 \text { papers /year) }\end{array}$ & $\begin{array}{l}80,000 \\
\text { with Rs. 2,600/year }\end{array}$ \\
\hline 14 & $\begin{array}{l}\text { Professor (Level 2) } \\
\text { Rs. 3,000 }\end{array}$ & $\begin{array}{l}\text { Full Time Master Degree in } \\
\text { Respective subject with } \\
60 \% \text {, Ph.D., } 20 \text { years } \\
\text { experience after Ph.D. } \\
\text { (Age } \leq 60)\end{array}$ & $\begin{array}{l}20 \text { years } \\
\text { (30 Journal Paper } \\
\& \& 5 \text { papers /year) }\end{array}$ & $\begin{array}{l}1,10,000 \\
\text { with Rs. 3,000/year }\end{array}$ \\
\hline 15 & Senior Professor & $\begin{array}{l}\text { Full Time Master Degree in } \\
\text { Respective subject with } \\
60 \% \text {, Ph.D., } 30 \text { years } \\
\text { experience after Ph.D. } \\
\text { (Age } \geq 60 \text { ) }\end{array}$ & $\begin{array}{l}30 \text { years } \\
(50 \text { journal Papers } \\
\& 6 \text { papers/year) }\end{array}$ & $\begin{array}{l}\text { Institutional } \\
\text { salary }\end{array}$ \\
\hline 16 & Emeritus Professor & $\begin{array}{l}\text { Full Time Master Degree in } \\
\text { Respective subject with } \\
60 \% \text {, Ph.D., } 30 \text { years } \\
\text { experience after Ph.D. } \\
\text { (Age } \geq 65 \text { ) till } 70 \text { years }\end{array}$ & $\begin{array}{l}30 \text { years } \\
(70 \text { journal Papers } \& \\
6 \text { papers/year) }\end{array}$ & $\begin{array}{l}\text { Institutional } \\
\text { salary }\end{array}$ \\
\hline
\end{tabular}


An example of Base Pay Scale :

Asst. Lecturer (I) : 18,000 - 800 - 30,000

Lecturer (I) : 22,000 - 1,000 - 36,000

Sr. Lecturer (I) : 27,000 - 1,200 - 39,000

Asst. Professor Level 1 (I) : 35.000 - 1,500 - 42,500

Asst. Professor Level 2 (I) : 43,000 - 1,600 - 59,000

Assoc Professor (I) : 51,000 - 1,800 - 69,000

Professor (I) : 60,000 - 2,000 - 80,000

Asst. Professor Level 1 (U) : 50,000 - 2,000 - 60,000

Asst. Professor Level 2 (U) : 60,000 - 2,000 - 64,000

Asst. Professor Level 3 (U) : 65,000 - 2,000 - 71,000

Assoc Professor (U) : 72,000 - 2,300 - 76,600 - 2,500 - 81,600

Professor (U) : 80,000 - 2,600 - 1,06,000

Senior Professor (U) : 1,10,000 - 3,000 - 1,40,000

Apart from Above Dearness Allowance can be given in \% and can be increased every year.

Table 5 :Grade equivalence at HEIs at USA and India

\begin{tabular}{|l|l|l|}
\hline S. No. & U. S. A. Faculty Grade & Indian Faculty Grade \\
\hline 1 & Teaching Assistant & Teaching Assistant \\
\hline 2 & Instructor & Assistant Lecturer \\
\hline 3 & Lecturer & Lecturer \\
\hline 4 & Sr. Lecturer & Sr. Lecturer \\
\hline 5 & Asst. Professor & Asst. Professor \\
\hline 6 & Associate Professor & Associate Professor \\
\hline 7 & Professor & Professor \\
\hline 8 & Senior Professor & Senior Professor \\
\hline 9 & Emeritus Professor & Emeritus Professor \\
\hline 10 & Adjunct Faculty & Visiting Faculty \\
\hline 11 & Visiting Faculty & Visiting Faculty \\
\hline
\end{tabular}

Table 6 : Chart representing how to calculate annual API score of a faculty member (as per UGC Standard).

I. API Scores for Research Papers, Books, Chapters \& Case Studies :

\begin{tabular}{|l|l|l|l|l|l|}
\hline $\begin{array}{l}\text { S. } \\
\text { No. }\end{array}$ & $\begin{array}{l}\text { Academic Performance Indicators } \\
\text { (APIs) }\end{array}$ & Sole Author & $\begin{array}{l}\text { Joint } \\
\text { Authors } \\
\text { (First } \\
\text { Author) }\end{array}$ & $\begin{array}{l}\text { Joint } \\
\text { Authors } \\
\text { (Other } \\
\text { Authors) }\end{array}$ & $\begin{array}{l}\text { Total } \\
\text { Maximum } \\
\text { API Score }\end{array}$ \\
\hline Research Papers published & 09 & 06 & 15 \\
\hline 1 & $\begin{array}{l}\text { Research Papers published in } \\
\text { Refereed and Indexed UGC } \\
\text { Recognized/Srinivas Journals }\end{array}$ & $\begin{array}{l}\mid \\
\text { Research Papers published in } \\
\text { Refereed and Scopus/SCI Indexed } \\
\text { Journals }\end{array}$ & 12 & 08 & 20 \\
\hline 3 & $\begin{array}{l}\text { Research Papers published in Non } \\
\text { UGC recognized but reputable } \\
\text { journals and periodicals, having }\end{array}$ & 10 & 06 & 04 & 10 \\
\hline
\end{tabular}

P. S. Aithal, (2018); www.srinivaspublication.com 
International Journal of Management, Technology, and Social

\begin{tabular}{|c|c|c|c|c|c|}
\hline & ISBN/ISSN numbers. & & & & \\
\hline 4 & $\begin{array}{l}\text { Research Papers published in } \\
\text { Conference proceedings as full } \\
\text { papers, etc. having ISBN. (Only } \\
\text { Abstracts not to be included) }\end{array}$ & 08 & 05 & 03 & 08 \\
\hline 5 & $\begin{array}{l}\text { Case Study Published in a Journal } \\
\text { with ISSN }\end{array}$ & 10 & 06 & 04 & 10 \\
\hline 6 & Patent Applied & 10 & 06 & 04 & 10 \\
\hline 7 & Indian Patent Accepted & 15 & 08 & 06 & 15 \\
\hline 8 & International Patent Accepted & 20 & 12 & 08 & 20 \\
\hline \multicolumn{6}{|c|}{ Books \&Chapters : } \\
\hline 9 & $\begin{array}{l}\text { (a) Text or Reference Books } \\
\text { Published by International } \\
\text { Publishers with an established peer } \\
\text { review system } \\
\text { (b) Chapters in the above books }\end{array}$ & 08 & 05 & 03 & 25 \\
\hline 10 & $\begin{array}{l}\text { (a) Subjects Books by National level } \\
\text { publishers/State and Central Govt. } \\
\text { Publications with ISBN/ISSN } \\
\text { numbers. } \\
\text { (b) Chapters in the above books }\end{array}$ & 20 & 10 & 10 & 20 \\
\hline 11 & $\begin{array}{l}\text { (a) Subject Books by Other local } \\
\text { publishers with ISBN numbers. } \\
\text { (b) Chapters in the above books }\end{array}$ & 15 & 09 & 06 & 15 \\
\hline 12 & $\begin{array}{l}\text { Study Material of } \\
\text { University subject as per Course } \\
\text { Syllabus }\end{array}$ & \multicolumn{3}{|c|}{$\begin{array}{l}\text { Compulsory } \\
\text { for every Faculty Member }\end{array}$} & - \\
\hline 13 & $\begin{array}{l}\text { Chapters contributed to edited } \\
\text { knowledge based volumes published } \\
\text { by International Publishers }\end{array}$ & 10 & 06 & 04 & 10 \\
\hline
\end{tabular}

II. API Scores for Research Projects, Research Guidance, Training Courses and Conference/Seminar/ Workshop Papers :

\begin{tabular}{|c|c|c|c|c|}
\hline $\begin{array}{l}\text { S. } \\
\text { No. }\end{array}$ & $\begin{array}{l}\text { Academic } \\
\text { Performance } \\
\text { Indicators (APIs) }\end{array}$ & $\begin{array}{l}\text { Engineering/ } \\
\text { Agriculture/ } \\
\text { Veterinary Science/ } \\
\text { Sciences/Medical } \\
\text { Sciences } \\
\end{array}$ & $\begin{array}{l}\text { Languages/Arts/ } \\
\text { Humanities/ Social } \\
\text { Sciences/ Library/ } \\
\text { Physicaleducation/ } \\
\text { Management }\end{array}$ & API Score \\
\hline \multicolumn{5}{|c|}{ 1. Research Projects } \\
\hline \multirow[t]{3}{*}{1} & \multirow[t]{3}{*}{$\begin{array}{l}\text { Funded projects } \\
\text { carried out/ ongoing }\end{array}$} & $\begin{array}{l}\text { (a) Major Projects } \\
\text { amount mobilized with } \\
\text { grants above } 30.0 \text { lakhs }\end{array}$ & $\begin{array}{l}\text { Major Projects } \text { with } \\
\text { grants above } 5.0 \\
\text { lakhs }\end{array}$ & $\begin{array}{l}20 \text { /each } \\
\text { Project }\end{array}$ \\
\hline & & $\begin{array}{l}\text { (b) Major Projects with } \\
\text { grants above } 5.0 \text { lakhs } \\
\text { to } 30.00 \text { lakhs }\end{array}$ & $\begin{array}{l}\text { Major Projects with } \\
\text { grantsminimum of Rs. } \\
3.00 \text { lakhs to Rs. } 5.00 \\
\text { lakh }\end{array}$ & $\begin{array}{l}15 \text { /each } \\
\text { Project }\end{array}$ \\
\hline & & $\begin{array}{lr}\text { (c) Minor } & \text { Projects } \\
\text { (Grants } & \text { above } \\
\end{array}$ & $\begin{array}{l}\text { Minor Projects (Grants } \\
\text { above Rs. }\end{array}$ & $\begin{array}{l}\text { 10/each } \\
\text { Project }\end{array}$ \\
\hline
\end{tabular}


International Journal of Management, Technology, and Social

\begin{tabular}{|c|c|c|c|c|}
\hline & & $\begin{array}{l}\text { Rs.50,000 to Rs. } 5 \\
\text { lakh) }\end{array}$ & 25,000 to Rs. 3 lakh) & \\
\hline 2 & $\begin{array}{l}\text { Consultancy Projects } \\
\text { carried out / ongoing }\end{array}$ & $\begin{array}{l}\text { Amount with minimum } \\
\text { of Rs. } 10.00 \text { lakh }\end{array}$ & $\begin{array}{l}\text { Amount with minimum } \\
\text { of Rs. } 2.0 \text { lakhs }\end{array}$ & $\begin{array}{l}\text { 10/ each } \\
\text { project }\end{array}$ \\
\hline 3 & Completed projects: & $\begin{array}{ll}\text { Completed } & \text { project } \\
\text { Report } & \end{array}$ & $\begin{array}{l}\text { Completed project } \\
\text { report }\end{array}$ & $\begin{array}{l}20 \text { /each major } \\
\text { project and } 10 \\
\text { / each minor } \\
\text { project }\end{array}$ \\
\hline 4 & $\begin{array}{l}\text { Projects Outcome / } \\
\text { Outputs }\end{array}$ & $\begin{array}{l}\text { Patent/Technology } \\
\text { transfer/ } \\
\text { Product/Process }\end{array}$ & $\begin{array}{l}\text { Major Policy document } \\
\text { of Govt. } \\
\text { Bodies at Central and } \\
\text { State level }\end{array}$ & $\begin{array}{l}30 \text { / each } \\
\text { national level } \\
\text { output or } \\
\text { patent / } 50 \\
\text { /each for } \\
\text { International } \\
\text { level. }\end{array}$ \\
\hline \multicolumn{5}{|c|}{ 2.Research Guidance } \\
\hline 5 & $\begin{array}{l}\text { M.Phil.(By research) } \\
\text { M.Tech. (By research) }\end{array}$ & $\begin{array}{l}\text { Degree awarded only } \\
\text { Degree awarded only } \\
\text { Degree awarded } \\
\text { Thesis submitted }\end{array}$ & & $\begin{array}{l}3 \text { /each } \\
\text { candidate } \\
3 \text { /each } \\
\text { candidate } \\
10 \text { /each } \\
\text { candidate } \\
7 \text { /each } \\
\text { candidate }\end{array}$ \\
\hline \multicolumn{5}{|c|}{ 3. Training Courses and Seminars/ Conferences/ Workshops } \\
\hline 6 & \multicolumn{2}{|c|}{$\begin{array}{l}\text { Refresher courses, Methodology workshops, } \\
\text { Training, Teaching-Learning- Evaluation } \\
\text { Technology Programmes, Soft Skills development } \\
\text { Programmes, Faculty Development Programmes } \\
\end{array}$} & $\begin{array}{l}\text { (a) Not less than two } \\
\text { weeks duration } \\
\text { (b) One week duration }\end{array}$ & $\begin{array}{l}\text { 20/each } \\
\text { 10/each }\end{array}$ \\
\hline 7 & $\begin{array}{l}\text { Papers in Conferences/ } \\
\text { Seminars/workshops } \\
\text { etc*. }\end{array}$ & \multicolumn{2}{|c|}{$\begin{array}{l}\text { Participation and Presentation of research papers } \\
\text { (oral/poster) in: } \\
\text { a) International conference } \\
\text { b) National } \\
\text { c) Regional/State level } \\
\text { d) Local -University/College level }\end{array}$} & $\begin{array}{l}10 / \text { each}^{* *} \\
7.5 / \text { each** } \\
5 \text { /each** } \\
3 \text { / each** }\end{array}$ \\
\hline 8 & $\begin{array}{l}\text { Invited lectures or } \\
\text { presentations for } \\
\text { conferences/Workshops/ } \\
\text { symposia }\end{array}$ & $\begin{array}{l}\text { a) International } \\
\text { b) National level }\end{array}$ & & $\begin{array}{l}10 / \text { each } \\
5 / \text { each }\end{array}$ \\
\hline
\end{tabular}

**If a paper presented in Conference/Seminar is published in the form of Proceedings, the points would accrue for the publication and not under presentation.

Table 7 :API based performance indicators \&proposed Compensation as dynamic component of the salary : (API score $1=$ Rs.200)

\begin{tabular}{|l|l|l|l|}
\hline S. No. & API Score & $\begin{array}{l}\text { Annual API based } \\
\text { Compensation (Rs.) }\end{array}$ & $\begin{array}{l}\text { Monthly component } \\
\text { (Rs.) }\end{array}$ \\
\hline 1 & 10 & 2,000 & 170 \\
\hline 2 & 20 & 4,000 & 340 \\
\hline
\end{tabular}


International Journal of Management, Technology, and Social

\begin{tabular}{|l|l|l|l|}
\hline 3 & 50 & 10,000 & 840 \\
\hline 4 & 100 & 20,000 & 1,670 \\
\hline 5 & 150 & 30,000 & 2,500 \\
\hline 6 & 200 & 40,000 & 3,350 \\
\hline 7 & 300 & 60,000 & 5,000 \\
\hline
\end{tabular}

\section{CASE EXAMPLES OF FACULTY PERFORMANCE MODEL :}

\section{Annual Target :}

Let us assume an HEI with 100 faculty members of different designations. The possible publications and the total cost of annual performance based pay per year is calculated using pessimistic estimate, most likely estimate, and optimistic estimate as in case 1 , case 2 , and case 3 respectively.

Case I : Pessimistic Estimate :

In this estimate, the HEI can expect 160 Journal
Papers (60 from faculty \& 100 from Research scholars) and 250 Conference Papers (100 from faculty \& 150 from Research Scholars\& Students). The total API score is calculated by allowing 15 scores per journal paper and 8 scores per conference proceedings paper. For 160 estimated journal papers publication and 250 conference proceedings paper, the institution gets total annual cost of $3,40,000$ per year for performance based salary component. The details of the calculation are given in table 8.

Table 8 :Pessimistic Estimate of organizational API and cost for faculty compensation

\begin{tabular}{|l|l|l|l|l|l|}
\hline $\begin{array}{l}\text { Faculty } \\
\text { Designation }\end{array}$ & $\begin{array}{l}\text { Number of } \\
\text { Faculty }\end{array}$ & $\begin{array}{l}\text { Journal } \\
\text { papers }\end{array}$ & $\begin{array}{l}\text { Conference } \\
\text { Papers }\end{array}$ & $\begin{array}{l}\text { Total API } \\
\text { score }\end{array}$ & $\begin{array}{l}\text { Annual cost of } \\
\text { Performance } \\
\text { based salary (Rs.) }\end{array}$ \\
\hline Professors & 10 & 10 & 20 & $150+160$ & 62,000 \\
\hline $\begin{array}{l}\text { Associated } \\
\text { Professors }\end{array}$ & 10 & 10 & 10 & $150+80$ & 46,000 \\
\hline $\begin{array}{l}\text { Assistant } \\
\text { Professors }\end{array}$ & 30 & 30 & 30 & $450+240$ & $1,38,000$ \\
\hline $\begin{array}{l}\text { Lecturers \& Senior } \\
\text { Lecturers }\end{array}$ & 50 & 10 & 40 & $150+320$ & 94,000 \\
\hline $\begin{array}{l}\text { Research Scholars } \\
\text { \& PG Students }\end{array}$ & $50+$ & 100 & 150 & - & - \\
\hline \begin{tabular}{l} 
Total \\
\hline
\end{tabular} & $150+$ & 250 & $\begin{array}{l}2,400+2,000 \\
=4,400\end{array}$ & $\begin{array}{l}3,40,000 / \text { year or } \\
28,000 / \text { Month }\end{array}$ \\
\hline
\end{tabular}

Case II :Most likely Estimate :

In this estimate, the HEI can expect 250 Journal Papers (150 from faculty \& 100 from Research scholars) and 400 Conference Papers (250 from faculty \& 150 from Research Scholars \& Students). The total API score is calculated by allowing 15 scores per journal paper and 8 scores per conference proceedings paper. For 250 estimated journal papers publication and 300 conference proceedings papers, the institution gets total annual cost of 6,90,000 per year for performance based salary component. The details of the calculation are given in table 9 .

Table 9 :Realistic Estimate of organizational API and cost for faculty compensation

\begin{tabular}{|l|l|l|l|l|l|}
\hline $\begin{array}{l}\text { Faculty } \\
\text { Designation }\end{array}$ & $\begin{array}{l}\text { Number of } \\
\text { Faculty }\end{array}$ & $\begin{array}{l}\text { Journal } \\
\text { papers }\end{array}$ & $\begin{array}{l}\text { Conference } \\
\text { Papers }\end{array}$ & $\begin{array}{l}\text { Total API } \\
\text { Score }\end{array}$ & $\begin{array}{l}\text { Annual cost of } \\
\text { Performance } \\
\text { based salary (Rs.) }\end{array}$ \\
\hline Professors & 10 & 20 & 20 & $300+160$ & 92,000 \\
\hline
\end{tabular}


International Journal of Management, Technology, and Social

\begin{tabular}{|l|l|l|l|l|l|}
\hline $\begin{array}{l}\text { Associated } \\
\text { Professors }\end{array}$ & 10 & 20 & 20 & $300+160$ & 92,000 \\
\hline $\begin{array}{l}\text { Assistant } \\
\text { Professors }\end{array}$ & 30 & 60 & 60 & $900+480$ & $2,76,000$ \\
\hline $\begin{array}{l}\text { Lecturers \& Senior } \\
\text { Lecturers }\end{array}$ & 50 & 50 & 50 & $750+400$ & $2,30,000$ \\
\hline $\begin{array}{l}\text { Research Scholars } \\
\text { \& PG Students }\end{array}$ & 50 & 100 & 150 & $1,500+1,200$ & - \\
\hline Total & 150 & 250 & 300 & $\begin{array}{l}3,450+2,700 \\
=6,150\end{array}$ & $\begin{array}{l}\text { 6,90,000/year or } \\
\text { 57,500/Month }\end{array}$ \\
\hline
\end{tabular}

Case III : Optimistic Estimate :

In this estimate, the HEI can expect 500 Journal Papers (300 from faculty \& 200 from Research scholars) and 600 Conference Papers (300 from faculty \& 300 from Research Scholars \& Students). The total API score is calculated by allowing 15 scores per journal paper and 8 scores per conference proceedings paper. For 500 estimated journal papers publication and 600 conference proceedings papers, the institution gets total annual cost of 13,80,000 per year for performance based salary component. The details of the calculation are given in table 10 .

Table 10 :Optimistic Estimate of organizational API and cost for faculty compensation

\begin{tabular}{|l|l|l|l|l|l|}
\hline $\begin{array}{l}\text { Faculty } \\
\text { Designation }\end{array}$ & $\begin{array}{l}\text { Number of } \\
\text { Faculty }\end{array}$ & $\begin{array}{l}\text { Journal } \\
\text { papers }\end{array}$ & $\begin{array}{l}\text { Conference } \\
\text { Papers }\end{array}$ & $\begin{array}{l}\text { Total API } \\
\text { Score }\end{array}$ & $\begin{array}{l}\text { Annual cost of } \\
\text { Performance } \\
\text { based salary (Rs.) }\end{array}$ \\
\hline Professors & 10 & 40 & 40 & $600+320$ & $1,84,000$ \\
\hline $\begin{array}{l}\text { Associated } \\
\text { Professors }\end{array}$ & 10 & 40 & 40 & $600+320$ & $1,84,000$ \\
\hline $\begin{array}{l}\text { Assistant } \\
\text { Professors }\end{array}$ & 30 & 120 & 120 & $1,800+960$ & $5,52,000$ \\
\hline $\begin{array}{l}\text { Lecturers \& Senior } \\
\text { Lecturers }\end{array}$ & 50 & 100 & 100 & $1500+800$ & $4,60,000$ \\
\hline $\begin{array}{l}\text { Research Scholars } \\
\text { \& PG Students }\end{array}$ & $50+$ & 200 & 300 & $3,000+2,400$ & - \\
\hline \begin{tabular}{l} 
Total \\
\hline
\end{tabular} & $150+$ & 500 & 600 & $\begin{array}{l}6,900+5,400 \\
=12,300\end{array}$ & $\begin{array}{l}13,80,000 / \text { year or } \\
1,15,000 / \text { Month }\end{array}$ \\
\hline
\end{tabular}

9. THEORY A BASED ANALYSIS OF FACULTY COMPENSATION PROPOSAL :

The faculty accountability based faculty compensation has four components. The base scale depends on their qualification and experience. Based on their overall performance (academic \& research) throughout the career the base pay grade can be decided. The conditional increment component (I) depends on the minimum research performance in a given year. Every faculty member is expected to do minimum research contribution to get annual increment so that it is named as the conditional increment. Instead of such minimum expected journal publications, a faculty member can earn equivalent API score by contributing any other intellectual property. The third component called dearness allowance also depends on Base scale and Annual Increment so that it also becomes a performance based component. The last component of the total scale called the annual performance based component depends on the annual academic performance indicator score. Hence the faculty compensation set research objective of the faculty, fix the target, motivates them for enhanced performance, set the action plan to maximize the performance using API, shows role models within the organization for 
comparison, and the total variable salary itself the accountability of the faculty members so that every faculty member will perform and contribute optimally to generate intellectual property in collaboration with their students, and colleagues of within the organization, and external to the organizations. This model allows faculty members to earn as much as they can and hence, they can decide the amount of their additional earning by contributing organizational intellectual property. Hence this model of additional earning based accountability both encourages performers and converts many nonperformers into performers.

\section{CONCLUSION :}

A model on variable faculty compensation distributed in monthly salary based on their individual research performance calculated using annual API score is proposed. It is expected that this model stimulates every faculty member and hence they will get anopportunity to earn as much as they can by active involvement in research and publications. The model inspires faculty members of autonomous HIEs especially of private universities to work in a bigger team including students, and colleagues who have interest in the similar research area within and outside the institutions for collaboration.This, in turn, increases the intellectual property (IP-1) of the HEIs. Thus, considering and implementing the option of annual performance based component in the faculty pay, HEI can increase their contributions to the research and publication and rename itself as higher education research institution/university.

\section{REFERENCES :}

[1] Aithal, P.S. \& Suresh Kumar, P.M. (2016). Opportunities and Challenges for Private Universities in India. International Journal of Management, IT and Engineering (IJMIE), $\quad$ 6(1), 88-113. DOI :http://doi.org/10.5281/zenodo.161157.

[2] Aithal, P.S. \& Suresh Kumar, P.M. (2017). Challenges and Opportunities for Research \& Publications in Higher Education. International Journal of Scientific Research and Modern Education (IJSRME), 2(1), 4249.

DOI: http://dx.doi.org/10.5281/zenodo.400 $\underline{619}$.

[3] Aithal, P.S. (2015). Strategy Development and Deployment in Higher Education Institutions. Elixir International Journal, 84 (1), 33594-33597. DOI: http://doi.org/10.5281/zenodo.266779.

[4] Aithal, P.S. (2015). How an effective leadership and governance supports to achieve institutional vision, mission and objectives. International Journal of Multidisciplinary Research and Development, 2 (5), 154-161. DOI: http://doi.org/10.5281/zenodo.266788.

[5] Srinivas Rao A., Suresh Kumar P.M., \& Aithal, P.S. (2015). Strategic Planning in Higher Education Institutions: A Case Study of SIMS - VISION 2025, International Journal of Educational Science and Research, 5(2), 29-42. DOI: http://doi.org/10.5281/zenodo.61589.

[6] Aithal P. S., Srinivas Rao A., \& Suresh Kumar, P.M., (2015). How Innovations and Best Practices can Transform Higher Education Institutions: A case study of SIMS. International Journal of Management (IJM), $\quad 6(2), \quad 83 \quad-\quad 98$. DOI:http://doi.org/10.5281/zenodo.61594.

[7] Aithal, P.S., Srinivas Rao A., \& Suresh Kumar P. M. (2015). Quality Enhancement in Higher Education Institutions: A case study of SIMS. International Journal of Multidisciplinary Research and Development, 2(5), 18-31. DOI: http://doi.org/10.5281/zenodo.266940.

[8] Aithal, P.S. (2015). Faculty Empowerment Strategies in Higher Education Institutions. International Journal of Management, IT and Engineering (IJMIE), 5(7), 108-115. DOI: http://doi.org/10.5281/zenodo.266967.

[9] Aithal, P.S. \& Suresh Kumar, P.M. (2015). Applying SWOC Analysis to an Institution of Higher Education. International Journal 
of Management, IT and Engineering (IJMIE), 5(7), 231-247. DOI: http://doi.org/10.5281/zenodo.163425.

[10] Aithal, P.S., Suresh Kumar, P.M. \&Deekshitha (2015). Societal Expectation and Institutional Accountability in Higher Education. International Journal of Management, IT and Engineering (IJMIE), 5(7), 361-373. DOI :http://doi.org/10.5281/zenodo.267021.

[11] Aithal, P.S., \& Suresh Kumar, P.M. (2016). Innovations in Private Universities: A Case of Srinivas University. International Journal of Management, IT and Engineering (IJMIE), 6(1), 250-264. DOI :http://doi.org/10.5281/zenodo.161151.

[12] Aithal, P.S. (2016). Creating Innovators through setting up organizational Vision, Mission and Core Values: a Strategic Model in Higher Education. International Journal of Management, IT and Engineering (IJMIE), 6(1), 310-324. DOI :http://doi.org/10.5281/zenodo.161147.

[13] Aithal, P.S. (2015). Strategies to be adopted in Higher Education Institutions to Enhance Admission Demand.International Journal of Extensive Research, 5, 9-25. DOI: http://doi.org/10.5281/zenodo.268530.

[14] Robert Ulewicz, (2017). The Role of Stakeholders in Quality Assurance in Higher Education. Human Resources Management \& Ergonomics, 11(1), 93-117.

[15] Aithal, P. S. \& Suresh Kumar, P.M., (2016). ABC Model of Research Productivity and Higher Educational Institutional Ranking. International Journal of Education and Management Engineering (IJEME), 6(6), 74-84. DOI: http://doi.org/10.5815/ijeme.2016.06.08.

[16] Aithal, P. S., Shailashree V.T. \& Suresh Kumar P.M., (2016). Analysis of ABC Model of Annual Research Productivity using ABCD Framework. International Journal of Current Research and Modern Education (IJCRME), 1(1), 846-858. DOI :http://doi.org/10.5281/zenodo.62022.
[17] Aithal, P.S. \& Suresh Kumar, P.M., (2016). ABC Model of Research Productivity and Higher Educational Institutional Ranking. International Journal of Education and Management Engineering (IJEME), 6(6), 74-84. DOI: http://doi.org/10.5815/ijeme.2016.06.08.

[18] Aithal, P.S. (2016). Study of Annual Research Productivity in Indian Top Business Schools. International Journal of Scientific Research and Modern Education (IJSRME), 1(1), 402-414.DOI :http://doi.org/10.5281/zenodo.161041.

[19] Aithal, P.S. (2016). Study of Research Productivity in World Top Business Schools.International Journal of Engineering Research and Modern Education (IJERME), 1(1), 629-644, DOI :http://doi.org/10.5281/zenodo.160969.

[20] Aithal, P.S. (2016). Research Performance Analysis of Some Indian Top Business Schools Using ABC Model. International Journal of Computational Research and Development, 1(1), 70-83. DOI :http://doi.org/10.5281/zenodo.163532.

[21] Aithal, P.S., (2016). Inspiring through SelfContribution - An Analysis of How Active the Indian Top Business School Directors in Research \& Publications. International Journal of Engineering Research and Modern Education (IJERME),1(2), 137 154.

DOI:http://dx.doi.org/10.5281/Zenodo.1646 90.

[22] Aithal, P.S., (2016). Excellence in Individual Research \&Publications : Examining the Active Role of Role models (Deans) of World Top Business Schools. International Journal of Engineering Research and Modern Education (IJERME), 1(2), 179199.DOI: http://dx.doi.org/10.5281/Zenodo. 192881.

[23] Aithal, P.S., Shailashree V. T. \& Suresh Kumar P. M., (2016). Analysis of ABC Model of Annual Research Productivity using ABCD Framework. International 
Journal of Current Research and Modern Education (IJCRME), 1(1), 846-858. DOI :http://doi.org/10.5281/zenodo.62022.

[24] Aithal, P.S. (2016). Research Performance Analysis of Some Indian Top Business Schools Using ABC Model. International Journal of Computational Research and Development, 1(1), 70-83. DOI :http://doi.org/10.5281/zenodo.163532.

[25] Aithal, P.S., (2016). Inspiring through SelfContribution - An Analysis of How Active the Indian Top Business School Directors in Research \& Publications. International Journal of Engineering Research and Modern Education (IJERME),1(2), 137 154.

DOI: http://dx.doi.org/10.5281/ZENODO.1 $\underline{64690}$.

[26] Kuh, G.D., \& Hu, S. (2001). Learning productivity at research universities. The Journal of Higher Education, 72(1), 1-28.

[27] Ash Merkel, C. (2003). Undergraduate research at the research universities. New Directions for teaching and learning, 2003(93), 39-54.

[28] Altbach, P.G. (2013). Advancing the national and global knowledge economy: the role of research universities in developing countries. Studies in higher education, 38(3), 316-330.

[29] Aithal, P.S., \& Suresh Kumar, P. M. (2016). Theory A for Optimizing Human Productivity. IRA-International Journal of Management \& Social Sciences, 4(3), 526535.

DOI

:http://doi.org/10.21013/jmss.v4.n3.p2.

[30] Aithal, P. S. and Suresh Kumar, P.M. (2016). Organizational Behaviour in $21^{\text {st }}$ Century - Theory A for Managing People for Performance. IOSR Journal of Business and Management (IOSR-JBM), 18(7), 126134. DOI: http://doi.org/10.9790/487X180704126134.

[31] Aithal, P.S.\& Suresh Kumar, P. M. (2016). Comparative Analysis of Theory X, Theory Y, Theory Z, and Theory A for Managing
People and Performance. International Journal of Scientific Research and Modern Education (IJSRME), 1(1), 803-812. DOI: http://doi.org/10.5281/zenodo.154600.

[32] Aithal, P. S. \& Suresh Kumar, P. M. (2016). CCE Approach through ABCD Analysis of 'Theory A' on Organizational Performance. International Journal of Current Research and Modern Education (IJCRME), 1(2), 169-185. DOI:http://doi.org/10.5281/zenodo.164704.

[33] Aithal, P.S. \& Suresh Kumar, P. M. (2016). Application of Theory A on ABC Model to enhance Organizational Research Productivity in Higher Education. International Journal of Advanced Trends in Engineering and Technology (IJATET), 1(1), 142-150. DOI :http://doi.org/10.5281/zenodo.240646.

[34] Aithal, P.S., Suresh Kumar P. M. (2017). Integrating Theory $\mathrm{A}$ and Six Thinking Hats for Improved Organizational Performance. International Journal of Applied Engineering and Management Letters (IJAEML), 1(2), 66-77. DOI: http://doi.org/10.5281/zenodo.1045417.

[35] Aithal, P.S. (2018). Effect of Role Models A Critical Study on the Recent Research Contribution of Vice-chancellors of Selected Private Universities in India. International Journal of Management, Technology, and Social Sciences (IJMTS), 3(1), 118-139. DOI :http://doi.org/10.5281/zenodo.1257729.

[36] Aithal, P.S., Kumar, Prasanna., \& Mike Dillon. (2018). How to Improve the Employee Productivity of Banking System in India - a Theory of Accountability Based Analysis. International Journal of Management, Technology, and Social Sciences (IJMTS), 3(2), 87-99. DOI :http://doi.org/10.5281/zenodo.1468380.

[37] Aithal, P.S. \& Suresh Kumar P. M., (2017). Interconnecting Theory A and ABC Model of Organizational Research Performance. International Journal of Management, Technology and Social Sciences 
(IJMTS),1(1), 1-13. DOI

:http://doi.org/10.5281/zenodo.268598.

[38] Aithal, P.S. \& Suresh Kumar, P. M. (2016). Application of Theory A on ABC Model to enhance Organizational Research Productivity in Higher Education. International Journal of Advanced Trends in Engineering and Technology (IJATET), $1(1), \quad 142-150 . \quad$ DOI :http://doi.org/10.5281/zenodo.240646.

[39] Aithal, P.S. (2016). How to Increase Research Productivity in Higher Educational Institutions -SIMS Model. International Journal of Scientific Research and Modern Education (IJSRME), 1(1), 447-458. DOI :http://doi.org/10.5281/zenodo.161037.

[40]Aithal, P. S. (2017). Comparison of Research Output and Fee Charging Strategies of Some Top Global \& Indian Business Schools. International Journal of Case Studies in Business, IT and Education (IJCSBE), 1(1), 53-66. DOI: http://dx.doi.org/10.5281/zenodo.584117. 